\title{
Association of the g.19074G $>$ A genetic variant in the osteoprotegerin gene with bone mineral density in Chinese postmenopausal women
}

Y.D. Zhang ${ }^{1 *}$, Z. Zhang ${ }^{1 *}$, N.F. Zhou ${ }^{1}$, W.T. Jia ${ }^{2}$, X.G. Cheng ${ }^{2}$ and X.J. Wei

${ }^{1}$ Department of Spine Surgery, Shanghai East Hospital, School of Medicine, Tongji University, Shanghai, China

${ }^{2}$ Department of Orthopedics,

The Affiliated Sixth People's Hospital of Shanghai Jiao Tong University, Shanghai, China

${ }^{3}$ College of Engineering, Peking University, Beijing,

China

*These authors contributed equally to this study.

Corresponding author: Y.D. Zhang

E-mail: yadongzhang_12@sina.com

Genet. Mol. Res. 13 (3): 6646-6652 (2014)

Received April 24, 2013

Accepted November 11, 2013

Published August 28, 2014

DOI http://dx.doi.org/10.4238/2014.August.28.9

\begin{abstract}
Primary osteoporosis is a common health problem in postmenopausal women. This study aimed to detect the association of the g.19074G $>$ A genetic variant in the osteoprotegerin gene $(O P G)$ with bone mineral density (BMD) and primary osteoporosis. The created restriction site-polymerase chain reaction method was used to investigate the g.19074G $>$ A genetic variant. The BMD of the femoral neck hip, lumbar spine $\left(\mathrm{L}_{2-4}\right)$, and total hip were assessed by dual-energy X-ray absorptiometry (DEXA) in 856 unrelated Chinese postmenopausal women. We found significant differences in the BMDs of the femoral neck hip, lumbar spine $\left(\mathrm{L}_{2-4}\right)$, and total hip among different genotypes; individuals with the GG genotype had significantly
\end{abstract}


higher BMDs than those with the GA and AA genotypes $(\mathrm{P}<0.05)$. Our results indicated that the A allele was an increased risk factor for primary osteoporosis and the g.19074G $>$ A genetic variant of the $O P G$ gene was associated with BMD and primary osteoporosis in Chinese postmenopausal women.

Key words: Bone mineral density; Genetic variant; Osteoprotegerin gene; Primary osteoporosis; Risk factor

\section{INTRODUCTION}

Primary osteoporosis is a common polygenic health problem, particularly in postmenopausal women. It is a multifactorial disorder characterized by a reduction in bone mineral density (BMD) and a deterioration of bone microarchitecture with a consequent increase of fracture risk (Cummings et al., 1985; Riggs and Melton, 1986; Peck et al., 1993; Kanis et al., 1994; Geng et al., 2007; Garcia-Unzueta et al., 2008; Li et al., 2012; Woo et al., 2012). Genetic factors play important roles in the pathogenesis of primary osteoporosis (Albagha and Ralston, 2006; Ferrari, 2008; Cheung et al., 2010; Hosoi, 2010; Ralston, 2010; Feng et al., 2012; Woo et al., 2012; Zhang et al., 2013). Evidence suggests that low BMD has high heritability. Low BMD is a major risk factor for primary osteoporosis (Nguyen et al., 2000; Lee et al., 2010; Ozbas et al., 2012). To date, several studies have reported that some functional genes, for example, the osteoprotegerin $(O P G)$ gene (Pocock et al., 1987; Hofbauer and Schoppet, 2002; Langdahl et al., 2002; Yamada et al., 2003; Arko et al., 2002, 2005; Vidal et al., 2011; Feng et al., 2012; Hussien et al., 2013; Zhang et al., 2013), the vitamin D receptor $(V D R)$ gene (Fang et al., 2005; Jakubowska-Pietkiewicz et al., 2012; Kurt et al., 2012; Li et al., 2012; Hussien et al., 2013; Horst-Sikorska et al., 2013), and the estrogen receptor alpha (ERalpha) gene (Kurt et al., 2012), affected BMD and primary osteoporosis. Among these candidate genes, $O P G$ is one of the most important. The potential association of the A163G, T245G, T950C, G1181C, C21775T, G23276A, and T23367C genetic variants of the $O P G$ gene with BMD and primary osteoporosis have been analyzed (Arko et al., 2002; Langdahl et al., 2002; Ohmori et al., 2002; Jorgensen et al., 2004; Zhao et al., 2005; Kim et al., 2007; Ueland et al., 2007; Garcia-Unzueta et al., 2008; Moffett et al., 2008; Lee et al., 2010; Feng et al., 2012; Zhang et al., 2013), and the results indicated that these genetic variants contributed to BMD and primary osteoporosis. However, the potential association between the g. $19074 \mathrm{G}>$ A genetic variant of $O P G$ and BMD and primary osteoporosis have not been reported. Therefore, the objective of this study was to detect this genetic variant and to assess its influence on BMD and primary osteoporosis.

\section{MATERIAL AND METHODS}

\section{Subjects}

In the present study, 425 Chinese postmenopausal osteoporosis women and 431 agematched healthy postmenopausal women were enrolled from the Affiliated East Hospital of Tongji University (Shanghai, China). All subjects were of Chinese Han nationality and lived 
in Shanghai City. Individuals with present or past history of diseases that might affect bone metabolism were excluded. All participants completed informed consent forms. This study was approved by the Ethics Committee of the Affiliated East Hospital of Tongji University (Shanghai, China).

\section{BMD measurement}

BMDs of the femoral neck hip, lumbar spine $\left(\mathrm{L}_{2-4}\right)$, and total hip were measured by dual-energy X-ray absorptiometry (DEXA) (Lunar Expert 1313; Lunar Corp.; USA). The BMD value was automatically calculated from bone mineral content $(\mathrm{g})$ and bone area $\left(\mathrm{cm}^{2}\right)$, and expressed as $\mathrm{g} / \mathrm{cm}^{2}$.

\section{Genotyping}

Peripheral venous blood was collected from each subject. Genomic DNA was isolated from blood using a DNA isolation kit (Invitrogen; Carlsbad, CA, USA). The primers for polymerase chain reaction (PCR) were designed through the Primer Premier 5.0 software (Premier Biosoft International; Palo Alto, CA, USA). Table 1 shows the PCR primers sequences, annealing temperature, PCR fragment size and region, and genotype size. The PCR was performed in $20 \mu \mathrm{L}$ mixtures, including $50 \mathrm{ng}$ mixed DNA template, $10 \mathrm{pM}$ of each primer, $0.20 \mathrm{mM} \mathrm{dNTP}, 2.5 \mathrm{mM} \mathrm{MgCl}_{2}$, and $0.5 \mathrm{U}$ Taq DNA polymerase (TaKaRa; Dalian, China). The protocol of PCR amplification was carried out at $95^{\circ} \mathrm{C}$ for 5 min followed by 32 cycles of $94^{\circ} \mathrm{C}$ for $30 \mathrm{~s}, 59.5^{\circ} \mathrm{C}$ for $30 \mathrm{~s}$, and $72^{\circ} \mathrm{C}$ for $30 \mathrm{~s}$, with a final extension at $72^{\circ} \mathrm{C}$ for $5 \mathrm{~min}$. The created restriction site-PCR (CRS-PCR) method was used to investigate the g.19074G $>$ A genetic variant. With one of the primers containing a nucleotide mismatch, the CRS-PCR method enabled the use of restriction enzymes for discriminating sequence variants (Yuan et al., 2012; 2013a, b). Five microliters of PCR amplified products were digested with 2 units selected MstI restriction enzymes (MBI Fermentas; St. Leon-Rot, Germany) at $37^{\circ} \mathrm{C}$ for $10 \mathrm{~h}$ and separated by electrophoresis. In order to confirm the genotype accuracy of CRS-PCR method, about 10\% random samples were investigated by DNA sequencing (ABI3730xl DNA Analyzer; Applied Biosystems, Foster City, CA, USA).

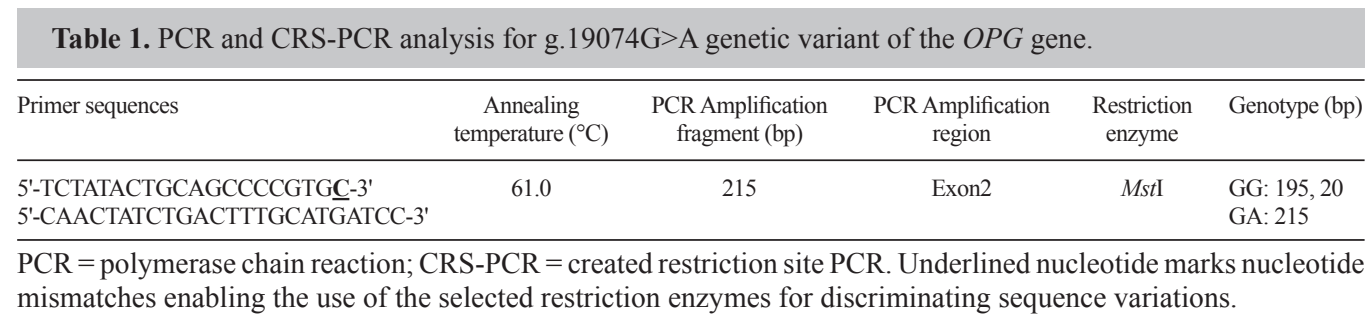

\section{Statistical analyses}

The chi-squared $\left(\chi^{2}\right)$ test was utilized to evaluate the Hardy-Weinberg equilibrium (HWE) for genotypic distributions. One-way analysis of variance (ANOVA) and the unpaired 
Student $t$-tests were used to evaluate the quantitative data. All data are reported as means \pm standard deviation (SD). The associations of variables were detected by multiple regression analyses. $\mathrm{P}<0.05$ was considered to be statistically significant level. All statistical analyses were analyzed with the Statistical Package for Social Sciences software (SPSS 14.0; SPSS Inc.; Chicago, IL, USA).

\section{RESULTS}

\section{$O P G$ genetic variant identification}

A total of 856 subjects were recruited for this study. We detected a novel genetic variant (g.19074G>A) in the $O P G$ gene for the subjects studied using the CRS-PCR method. The sequence analyses suggested that this genetic variant is a non-synonymous mutation in exon2 at position 19074 of the $O P G$ gene that is caused by a $\mathrm{G} \rightarrow \mathrm{A}$ mutation, and resulted in a cysteine (Cys) to tyrosine (Tyr) amino acid replacement (p.Cys87Tyr; reference sequence GenBank IDs: NG_012202.1, NM_002546.3, NP_002537.3). The PCR amplified products were digested with the MstI selected restriction enzyme and divided into three genotypes: GG (195 bp and $20 \mathrm{bp}$ ), GA (215 bp, $195 \mathrm{bp}$, and $20 \mathrm{bp}$ ), and AA (215 bp) (Table 1).

\section{Allelic and genotypic distributions}

All three possible genotypes of the g.19074G $>$ A genetic variant for the populations studied were found. The allelic and genotypic distributions of this genetic variant in primary osteoporosis cases and healthy controls are shown in Table 2 . The G allele and the GG genotype were predominant in the subjects studied. The results of the $\chi^{2}$ test suggested that the distributions of genotype conformed to HWE $(\mathrm{P}>0.05)$.

\begin{tabular}{|c|c|c|c|c|c|c|c|}
\hline \multirow[t]{2}{*}{ Groups } & \multicolumn{3}{|c|}{ Genotypic frequencies (\%) } & \multicolumn{2}{|c|}{ Allelic frequencies (\%) } & \multirow[t]{2}{*}{$\chi^{2}$} & \multirow[t]{2}{*}{$P$} \\
\hline & GG & GA & $\mathrm{AA}$ & G & A & & \\
\hline Case group ( $N=425)$ & $183(43.06)$ & $174(40.94)$ & $68(16.00)$ & $540(63.53)$ & $310(36.47)$ & 5.7670 & 0.0559 \\
\hline Control group $(\mathrm{N}=431)$ & $206(47.80)$ & $180(41.76)$ & $45(10.44)$ & $592(68.68)$ & $270(31.32)$ & 0.3695 & 0.8313 \\
\hline \multirow[t]{2}{*}{ Total $(\mathrm{N}=856)$} & $389(45.44)$ & $354(41.36)$ & $113(13.20)$ & $1132(66.12)$ & $580(33.88)$ & 5.0666 & 0.0794 \\
\hline & \multicolumn{3}{|c|}{$\chi^{2}=6.1013, \mathrm{P}=0.0473$} & \multicolumn{2}{|c|}{$\chi^{2}=5.0634, \mathrm{P}=0.0244$} & & \\
\hline
\end{tabular}

\section{Association analyses}

The age, height, weight, body mass index (BMI), femoral neck hip BMD, spine BMD, and total hip BMD in each genotype group are shown in Table 3. The BMD values were adjusted by age, height, and weight. We found significant differences in the BMDs of the femoral neck hip, lumbar spine $\left(\mathrm{L}_{2-4}\right)$, and total hip among different genotypes in the studied subjects; individuals with the GG genotype had significantly higher BMDs than those with the GA and AA genotypes $(\mathrm{P}<0.05$, Table 3$)$. 
Table 3. Characteristics of g. $19074 \mathrm{G}>$ A genetic variant in the total subjects.

\begin{tabular}{lcccc}
\hline Genotype & GG & GA & AA & P \\
\hline Number $(\%)$ & $389(45.44)$ & $354(41.36)$ & $113(13.20)$ & - \\
Age $($ years $)$ & $61.8 .3 \pm 7.6$ & $62.9 \pm 8.1$ & $63.2 \pm 7.8$ & 0.411 \\
Height $(\mathrm{cm})$ & $161 \pm 7.2$ & $162 \pm 7.8$ & $164 \pm 6.8$ & 0.256 \\
Weight $(\mathrm{kg})$ & $61.2 \pm 6.6$ & $61.6 \pm 6.9$ & $62.2 \pm 7.7$ & 0.321 \\
BMI & $23.1 \pm 3.11$ & $23.2 \pm 3.22$ & $23.5 \pm 3.53$ & 0.318 \\
Femoral neck hip BMD $\left(\mathrm{g} / \mathrm{cm}^{2}\right)$ & $0.752 \pm 0.183$ & $0.689 \pm 0.148$ & $0.667 \pm 0.213$ & 0.035 \\
Spine BMD $\left(\mathrm{g} / \mathrm{cm}^{2}\right)$ & $0.956 \pm 0.137$ & $0.876 \pm 0.111$ & $0.842 \pm 0.219$ & 0.046 \\
Total hip BMD $\left(\mathrm{g} / \mathrm{cm}^{2}\right)$ & $0.895 \pm 0.117$ & $0.831 \pm 0.142$ & $0.820 \pm 0.289$ & 0.035 \\
\hline
\end{tabular}

$\mathrm{BMD}=$ bone mineral density (BMD values adjusted by age, height and weight); $\mathrm{BMI}=$ body mass index; Data are reported as means \pm standard deviation.

\section{DISCUSSION}

Primary osteoporosis is a common health disease in postmenopausal women and is caused by the effects combined of genetic and environmental factors. Genetic factors play key roles in the development of primary osteoporosis. Recent studies indicated that the $O P G$ gene is an important candidate gene influencing BMD and primary osteoporosis (Pocock et al., 1987; Hofbauer and Schoppet, 2002; Langdahl et al., 2002; Yamada et al., 2003; Arko et al., 2002, 2005; Vidal et al., 2011; Feng et al., 2012; Hussien et al., 2013; Zhang et al., 2013). Several genetic variants of the $O P G$ gene have been analyzed and the results suggested that these genetic variants could mediate the effects of BMD and primary osteoporosis (Pocock et al., 1987; Hofbauer and Schopppet, 2002; Langdahl et al., 2002; Yamada et al., 2003; Arko et al., 2002, 2005; Vidal et al., 2011; Feng et al., 2012; Hussien et al., 2013; Zhang et al., 2013). In the present study, one novel genetic variant (g.19074G $>$ A) in the $O P G$ gene was detected using CRS-PCR and verified with DNA sequencing methods. Our data indicated a significant association between this genetic variant and BMD and primary osteoporosis in Chinese postmenopausal women; individuals with the GG genotype had significantly higher BMD values than those with GA and AA genotypes $(\mathrm{P}<0.05$, Table 3$)$. Results from this study suggested that the A allele might confer an increased risk for BMD and primary osteoporosis in Chinese postmenopausal women. To date, several similar studies have reported potential associations of many genetic variants of the $O P G$ gene (for example, A163G, T245G, T950C, G1181C, C21775T, G23276A, and T23367C) with BMD and primary osteoporosis. Results from these observations are consistent with our conclusion that the genetic variants of the $O P G$ gene may contribute to BMD and primary osteoporosis (Arko et al., 2002; Langdahl et al., 2002; Ohmori et al., 2002; Jorgensen et al., 2004; Zhao et al., 2005; Kim et al., 2007; Ueland et al., 2007; Garcia-Unzueta et al., 2008; Moffett et al., 2008; Lee et al., 2010; Feng et al., 2012; Zhang et al., 2013). Our results could provide more evidence to explain the role of the $O P G$ gene in the development of primary osteoporosis. Several other non-synonymous genetic variants, such as Lysine (Lys)3 Asparagine (Asn), Isoleucine (Ile)184 Methionine (Met) and Threonine (Thr)154Met, have been significantly associated with the risk of BMD and primary osteoporosis and were shown to influence the function of the OPG protein (Zhao et al., 2005; Feng et al., 2012; Zhang et al., 2013). The g.19074G $>$ A genetic variant of the $O P G$ gene might be linked to these non-synonymous genetic variants and have similar functions in the development of primary osteoporosis. Functional studies on larger, different populations with respect to the g.19074G $>$ A variant and other genetic variants spanning the whole $O P G$ gene region 
are necessary to clarify the underlying molecular mechanisms and pathophysiology of this association.

\section{Conflicts of interest}

The authors declare no conflict of interest.

\section{ACKNOWLEDGMENTS}

Research supported by the Shanghai Healthcarer Bureau Scientific Fund (\#2011Y249).

\section{REFERENCES}

Albagha OM and Ralston SH (2006). Genetics and osteoporosis. Rheum. Dis. Clin. North Am. 32: 659-680.

Arko B, Prezelj J, Komel R, Kocijancic A, et al. (2002). Sequence variations in the osteoprotegerin gene promoter in patients with postmenopausal osteoporosis. J. Clin. Endocrinol. Metab. 87: 4080-4084.

Arko B, Prezelj J, Kocijancic A, Komel R, et al. (2005). Association of the osteoprotegerin gene polymorphisms with bone mineral density in postmenopausal women. Maturitas 51: 270-279.

Cheung CL, Xiao SM and Kung AW (2010). Genetic epidemiology of age-related osteoporosis and its clinical applications. Nat. Rev. Rheumatol. 6: 507-517.

Cummings SR, Kelsey JL, Nevitt MC and O' Dowd KJ (1985). Epidemiology of osteoporosis and osteoporotic fractures. Epidemiol. Rev. 7: 178-208.

Fang Y, van Meurs JB, d'Alesio A, Jhamai M, et al. (2005). Promoter and 3'-untranslated-region haplotypes in the vitamin $\mathrm{d}$ receptor gene predispose to osteoporotic fracture: the rotterdam study. Am. J. Hum. Genet. 77: 807-823.

Feng G, Meng L, Wang H, Lu Y, et al. (2012). Single-nucleotide polymorphism of the osteoprotegerin gene and its association with bone mineral density in Chinese postmenopausal women. J. Pediatr. Endocrinol. Metab. 25: 11411144.

Ferrari S (2008). Human genetics of osteoporosis. Best Pract. Res. Clin. Endocrinol. Metab. 22: 723-735.

Garcia-Unzueta MT, Riancho JA, Zarrabeitia MT, Sanudo C, et al. (2008). Association of the 163A/G and 1181G/C osteoprotegerin polymorphism with bone mineral density. Horm. Metab. Res. 40: 219-224.

Geng L, Yao Z, Yang H, Luo J, et al. (2007). Association of CA repeat polymorphism in estrogen receptor $\beta$ gene with postmenopausal osteoporosis in Chinese. J. Genet. Genomics 34: 868-876.

Hofbauer LC and Schoppet M (2002). Osteoprotegerin gene polymorphism and the risk of osteoporosis and vascular disease. J. Clin. Endocrinol. Metab. 87: 4078-4079.

Horst-Sikorska W, Dytfeld J, Wawrzyniak A, Marcinkowska M, et al. (2013). Vitamin D receptor gene polymorphisms, bone mineral density and fractures in postmenopausal women with osteoporosis. Mol. Biol. Rep. 40: 383-390.

Hosoi T (2010). Genetic aspects of osteoporosis. J. Bone Miner. Metab. 28: 601-607.

Hussien YM, Shehata A, Karam RA, Alzahrani SS, et al. (2013). Polymorphism in vitamin D receptor and osteoprotegerin genes in Egyptian rheumatoid arthritis patients with and without osteoporosis. Mol. Biol. Rep. 40: 3675-3680.

Jakubowska-Pietkiewicz E, Mlynarski W, Klich I, Fendler W, et al. (2012). Vitamin D receptor gene variability as a factor influencing bone mineral density in pediatric patients. Mol. Biol. Rep. 39: 6243-6250.

Jorgensen HL, Kusk P, Madsen B, Fenger M, et al. (2004). Serum osteoprotegerin (OPG) and the A163G polymorphism in the OPG promoter region are related to peripheral measures of bone mass and fracture odds ratios. J. Bone Miner. Metab. 22: 132-138.

Kanis JA, Melton LJ, III, Christiansen C, Johnston CC, et al. (1994). The diagnosis of osteoporosis. J. Bone Miner. Res. 9: 1137-1141.

Kim JG, Kim JH, Kim JY, Ku SY, et al. (2007). Association between osteoprotegerin (OPG), receptor activator of nuclear factor-kappaB (RANK), and RANK ligand (RANKL) gene polymorphisms and circulating OPG, soluble RANKL levels, and bone mineral density in Korean postmenopausal women. Menopause. 14: 913-918.

Kurt O, Yilmaz-Aydogan H, Uyar M, Isbir T, et al. (2012). Evaluation of ERalpha and VDR gene polymorphisms in relation to bone mineral density in Turkish postmenopausal women. Mol. Biol. Rep. 39: 6723-6730.

Langdahl BL, Carstens M, Stenkjaer L and Eriksen EF (2002). Polymorphisms in the osteoprotegerin gene are associated 
with osteoporotic fractures. J. Bone Miner. Res. 17: 1245-1255.

Lee YH, Woo JH, Choi SJ, Ji JD, et al. (2010). Associations between osteoprotegerin polymorphisms and bone mineral density: a meta-analysis. Mol. Biol. Rep. 37: 227-234.

Li Y, Xi B, Li K and Wang C (2012). Association between vitamin D receptor gene polymorphisms and bone mineral density in Chinese women. Mol. Biol. Rep. 39: 5709-5717.

Moffett SP, Oakley JI, Cauley JA, Lui LY, et al. (2008). Osteoprotegerin Lys3Asn polymorphism and the risk of fracture in older women. J. Clin. Endocrinol. Metab. 93: 2002-2008.

Nguyen TV, Blangero J and Eisman JA (2000). Genetic epidemiological approaches to the search for osteoporosis genes. J. Bone Miner. Res. 15: 392-401.

Ohmori H, Makita Y, Funamizu M, Hirooka K, et al. (2002). Linkage and association analyses of the osteoprotegerin gene locus with human osteoporosis. J. Hum. Genet. 47: 400-406.

Ozbas H, Tutgun OS and Ozdamar K (2012). Genetic and environmental factors in human osteoporosis. Mol. Biol. Rep. 39: 11289-11296.

Peck WA, Burkhardt P, Christiansen C, Fleisch HA, et al. (1993). Consensus development conference: diagnosis, prophylaxis, and treatment of osteoporosis. Am. J. Med. 94: 646-650.

Pocock NA, Eisman JA, Hopper JL, Yeates MG, et al. (1987). Genetic determinants of bone mass in adults. A twin study. J. Clin. Invest. 80: 706-710.

Ralston SH (2010). Genetics of osteoporosis. Ann. N. Y. Acad. Sci. 1192: 181-189.

Riggs BL and Melton LJ, III (1986). Involutional osteoporosis. N. Engl. J. Med. 314: 1676-1686.

Ueland T, Bollerslev J, Wilson SG, Dick IM, et al. (2007). No associations between OPG gene polymorphisms or serum levels and measures of osteoporosis in elderly Australian women. Bone 40: 175-181.

Vidal C, Formosa R and Xuereb-Anastasi A (2011). Functional polymorphisms within the TNFRSF11B (osteoprotegerin) gene increase the risk for low bone mineral density. J. Mol. Endocrinol. 47: 327-333.

Woo J, Kim Y and Lee C (2012). Heterogeneous genetic associations of nucleotide sequence variants with bone mineral density by gender. Mol. Biol. Rep. 39: 2259-2265.

Yamada Y, Ando F, Niino N and Shimokata H (2003). Association of polymorphisms of the osteoprotegerin gene with bone mineral density in Japanese women but not men. Mol. Genet. Metab. 80: 344-349.

Yuan Z, Li J, Li J, Zhang L, et al. (2012). Investigation on BRCA1 SNPs and its effects on mastitis in Chinese commercial cattle. Gene 505: 190-194.

Yuan Z, Li J, Li J, Gao X, et al. (2013a). SNPs identification and its correlation analysis with milk somatic cell score in bovine MBL1 gene. Mol. Biol. Rep. 40: 7-12.

Yuan Z, Li J, Li J, Gao X, et al. (2013b). Effects of DGAT1 gene on meat and carcass fatness quality in Chinese commercial cattle. Mol. Biol. Rep. 40: 1947-1954.

Zhang F, He C, Chen G, Li F, et al. (2013). Association analyses of osteoprotegerin gene polymorphisms with bone mineral density in Chinese postmenopausal women. Med. Oncol. 30: 389.

Zhao HY, Liu JM, Ning G, Zhao YJ, et al. (2005). The influence of Lys3Asn polymorphism in the osteoprotegerin gene on bone mineral density in Chinese postmenopausal women. Osteoporos. Int. 16: 1519-1524. 